The University of Maine

DigitalCommons@UMaine

Publications

Senator George J. Mitchell Center for Sustainability

Solutions

$1-2015$

\title{
Tidal Power Development in Maine: Stakeholder Identification and Perceptions of Engagement
}

Teresa R. Johnson

University of Maine - Main, teresa.johnson@maine.edu

Jessica Spelke Jansujwicz

University of Maine, jessica.jansujwicz@maine.edu

Follow this and additional works at: https://digitalcommons.library.umaine.edu/ mitchellcenter_pubs

\section{Repository Citation}

Johnson, Teresa R. and Jansujwicz, Jessica Spelke, "Tidal Power Development in Maine: Stakeholder Identification and Perceptions of Engagement" (2015). Publications. 62.

https://digitalcommons.library.umaine.edu/mitchellcenter_pubs/62

This Article is brought to you for free and open access by DigitalCommons@UMaine. It has been accepted for inclusion in Publications by an authorized administrator of DigitalCommons@UMaine. For more information, please contact um.library.technical.services@maine.edu. 


\section{Tidal Power Development in Maine: Stakeholder Identification and Perceptions of Engagement}

Teresa R. Johnson, Jessica S. Jansujwicz, Gayle Zydlewski

T. R. Johnson, G. Zydlewski

School of Marine Sciences, University of Maine, 200 Libby Hall, Orono, ME 04469, USA

e-mail: teresa.johnson@maine.edu

J. S. Jansujwicz

Sustainability Solutions Initiative, University of Maine, 5710 Norman Smith Hall, Orono, ME 04469, USA 
Development of renewable energy affects or is affected by numerous stakeholders. Understanding who the stakeholders are and how they are engaged in the process is necessary for improving the responsible development of renewable energy technologies. Using structured community interviews and in-depth ethnographic research (semi-structured interviews, informal interviews, observations, and document review), we identified and characterized the most salient stakeholders associated with tidal power development in Maine and documented stakeholder perceptions of developer engagement strategies. Stakeholder characterization was facilitated using a framework by Mitchell et al. (The Academy of Management Review 22:853-886, 1997) that characterizes salient stakeholders using attributes of power, urgency, and legitimacy. Key stakeholders identified include fishermen, community members, tribes, regulators, developers, and scientists. Fishermen and regulators are definitive stakeholders, with legitimacy, power, and urgency in the process. Tribes are considered dominant stakeholders; they have legitimacy and power, but their interests are, at this time, not viewed as urgent. Scientists are considered to have urgency and power. The developers viewed their stakeholder engagement strategy as open and transparent. Community stakeholders, regulators, and fishermen generally perceived the developer's approach as effective; they noted the company's accessibility and their efforts to engage stakeholders early and often. Given the dynamic nature of stakeholder salience, our findings highlight the importance of engaging dominant stakeholders so that future conflict can be more easily avoided as new information develops. Our approach can be used to inform stakeholder identification and engagement research in other renewable energy contexts.

Keywords: Renewable energy, Tidal power, Stakeholder engagement, Stakeholder identification, Public perception 
INTRODUCTION

From mitigating climate change to improving national security and providing economic stability, renewable energy is viewed as a solution to some of our most challenging social and environmental problems (El Bassam 2001; Elliott 2000). Development of renewable energy, however, is a complex process that affects or is affected by numerous individuals, groups, and organizations. Understanding who may be affected, how they are affected, and how they are (or would like to be) engaged in the decision-making process is critically important to move renewable energy development forward in a socially and environmentally responsible manner. Attention to interested parties or stakeholders is needed to assess and enhance political feasibility (Meltsner 1972; Eden and Ackermann 1998; van Horn et al. 2001), understand public attitudes (Portman 2009; Reddy and Painuly 2004; Westetal. 2010; Devine-Wright 2005; Firestone and Kempton 2007; Firestone et al. 2009; Kempton et al. 2005), and design more effective stakeholder processes (Hindmarsh and Mathews 2008; Conwayetal. 2010).

Opportunities for stakeholder input are considered critical in not-in-my-backyard arenas, like renewable energy (Conway et al. 2010; Portman 2009). As Adams et al. (2011) argue, a fundamental transformation in energy strategies away from dependence on imported, nonrenewable fuels to adoption of strategies such as renewable energy development is unlikely to occur without a high level of stakeholder engagement. Stakeholder participation is distinguished from broader public participation and is defined as a process where individuals, groups, and organizations choose to take an active role in decisions that affect them (Reed 2008). There are many claimed benefits of stakeholder participation in environmental decision-making (Reed 2008), including developing trust (Richards et al. 2004) and acceptability (Breukers and Wolsink 2007); improving transparency, accountability, and understanding (Zoellner et al. 2008; Agterbosch et al. 2009); and enhancing the quality and durability of decisions (Reed 2008; Breukers and Wolsink 2007). It is thought that if people feel left out of the planning process and decision-making, they will 
be more likely to oppose the process outcome (Zoellner et al. 2008). It is also claimed that stakeholder participation promotes social learning (Blackstock et al. 2007) and increases the likelihood that local needs and priorities are successfully met in the decision-making process. Engaging stakeholders may serve to broaden the number of dimensions considered for problem solving (Holmes and Scoones 2000) and, in particular, may allow for nontechnical information provided by nonscientists to enter the decision-making process (Glicken 2000).

In practice, however, stakeholder participation may not be meeting these idealized claims (Reed 2008). Integrating input from numerous and diverse stakeholders into on-going decision-making processes is a significant challenge (Glicken 2000), and more effective stakeholder participation will require an improved understanding of how to engage relevant stakeholders at the most appropriate time and in a manner that will enable them to fairly and effectively shape decisions (Reed 2008).

The first step in designing more effective stakeholder engagement processes is identifying and characterizing stakeholders (Reed et al. 2009). Originating from the fields of organizational management and business ethics, a stakeholder is "any group or individual who can affect or is affected by the achievement of the organization's objectives"(Freeman 1984,p.46). The term refers to persons, groups, or organizations that somehow must be taken into account by leaders and managers (Bryson 2004). Although the literature offers multiple definitions of stakeholder, one common feature of all definitions is that they identify and define groups related to a specific issue (Glicken 2000). Deciding how to define stakeholders in a particular management context is consequential, as the decision affects who and what counts (Mitchell et al. 1997). Taking stakeholders into account is a crucial aspect of problem solving (Bryson and Crosby 1992; Bardach 1998), and stakeholder identification is relevant to planning for stakeholder participation (Bryson 2004).

The literature is replete with approaches to facilitate stakeholder identification and characterization. For example, Newman and Lamming (1995) divide stakeholders into those who will use a system directly or 
indirectly and those who will be involved in developing the system. While these divisions may offer a useful starting point, as Sharp et al. (1999) note, the literature does not provide help in identifying stakeholders for a particular system or relevant to a particular project. Rather, they find that "approaches are criticized for either assuming that stakeholders are 'obvious' or for providing broad categories which are too generic to be of practical use (Sharp et al. 1999, p.388)." Given the importance of the management context, structuring effective engagement requires a better understanding of the perspectives, concerns, and information needs of the different stakeholder groups that may affect or be affected by the decision-making process. Choices of who to include, how, when, and why are related to the questions of effectiveness and to the value of that particular stakeholder's engagement (Bryson 2004).

In this study, we draw on findings from ethnographic research to identify and characterize stakeholders relevant to a tidal energy project in Maine and to document perceptions of the developer's stakeholder engagement strategy. Our focus is on the development of renewable energy technologies, specifically marine hydrokinetic devices (MHK) that capture the kinetic energy of the water when placed in the free-flowing tidal stream (Charlier and Finkl 2010). MHK devices represent a new generation of tidal energy technology and significant uncertainty remains about the impacts of these technologies on social and environmental systems (Gill 2005; Boehlert and Gill 2010; Polagye et al. 2011; Johnson et al. 2012). Despite this uncertainty, interest in tidal power development is rapidly increasing (e.g., over 80 preliminary permits issues in the USA; FERC. http://www.ferc.gov/industries/hydropower/gen-info/ licensing/hydrokinetics.asp), and decisions are currently being made about MHK development in multi-use coastal ecosystems. Tidal power development occurs in geographically restricted coastal areas, close to shore where interaction with other human uses is high. As a consequence, multiple stakeholders may affect or be affected by tidal power development decisions (Johnson and Zydlewski 2012).

The Maine-based Ocean Renewable Power Company (ORPC) is currently developing two MHK sites in eastern Maine that are furthest along in development in the USA. In this region, the tides rise and fall on 
average $7 \mathrm{~m}$ twice per day, and there is a history of attempts to harness power from these tides (Fig. 1). The efforts of ORPC have been praised as a model for stakeholder engagement in the arena of ocean energy development (Beard 2009). In Maine, the Governor's Ocean Energy Taskforce (OETF) concluded that, "Ocean energy developers will gain trust, understanding, and possible support, from a variety of local stakeholders by adopting the best practices in public engagement... demonstrated by the ORPC-Eastport example" (Ocean Energy Task Force OETF 2009). Early in the development process, ORPC held a series of public meetings in the community and met with local authorities and opinion leaders to discuss their development plans and receive feedback on issues such as the specific site for turbine deployment in Cobscook Bay. ORPC also initiated early consultation with federal and state agencies to kick off the regulatory and permitting process (Jansujwicz and Johnson 2013).

Three key questions guided our inquiry of ORPC's Cobscook Bay Tidal Energy Project: Who are the most salient stakeholders associated with tidal energy development? What kinds of engagement strategies are considered effective for these stakeholders? How can we use this information to inform future engagement strategies?

\section{CONCEPTUAL FRAMEWORK}

We used a typology developed by Mitchell et al. (1997) to organize our research findings and characterize stakeholders related to tidal energy development. In their typology, Mitchell et al. (1997) define salience as "the degree to which managers give priority to competing stakeholder claims." In this framework, categories of stakeholders can be identified based on their power, legitimacy, and urgency. Power is relational; it refers to the ability to bring about the outcomes one desires. Legitimacy refers to those that have a legal, moral, or presumed claim. Urgency refers to individuals or organizations that deserve immediate attention from the decision-makers. All of these attributes are variable and socially constructed. 
These attributes lend themselves to a stakeholder typology depending on which of the attributes exist. For example, stakeholder salience, where individuals are given priority over competing stakeholders' claims, is high where all three attributes exist (legitimacy, power, and urgency); these are the definitive stakeholders. Individuals or groups viewed as having power and legitimacy are considered dominant stakeholders. Those with legitimacy and urgency are dependent stakeholders. Those with only urgency and power are considered dangerous stakeholders. Discretionary stakeholders are those with only legitimacy. Dormant stakeholders are those with power, but lack legitimacy and urgency. Demanding stakeholders are those with urgency, but lack power and legitimacy. Those lacking any of these attributes are not considered stakeholders.

We applied the typology of Mitchell et al. (1997) to our case of tidal power development in Maine. Specifically, we use the classification system to categorize stakeholders identified in our social science research, although we recognize that the variable and socially constructed nature of the attribute-based classification system means that this is only one of several possible interpretations. As Parent and Deephouse (2007) note, the Mitchell et al. (1997) framework has been widely cited, but empirical research using the framework has been limited. We find that most citations are drawn from fields of business management and ethics, and to our knowledge, the framework has not been used to inform stakeholder identification in the arena of renewable energy development, although it has been applied to fisheries management (Mikalsen and Jentoft 2001). Our study investigates the utility of using Mitchell et al.'s framework as a tool to inform stakeholder identification and engagement for the responsible development of tidal power. In the process, we offer an empirical analysis that uses the framework of Mitchell et al. (1997). In addition to using this framework as a tool for describing stakeholders (and for applying the theory of stakeholder salience to practice), we explore the utility of using the framework as a tool to inform engagement by identifying recommendations for including salient stakeholders in the decision-making process. 
We used archival documents and our observations to determine three initial stakeholder groups: developers, regulators, and community members. We used a mixed methods approach, consisting of structured community interviews and in-depth ethnographic research (semi-structured interviews, focus groups, informal interviews, observations, and document review) to develop an initial overview of the setting for tidal energy development in the area of Cobscook Bay and to characterize those that may affect or be affected by the development process. We did not want to presume a priori all of the relevant stakeholders, but instead we wanted to identify these through our research. Below we describe our specific methods to further characterize the three broad categories of stakeholders and to document stakeholder engagement experiences.

Community - In order to identify community stakeholders and their concerns, we adopted a participatory approach and partnered with the Maine Sea Grant and University of Maine Cooperative Extension and the Cobscook Bay Resource Center. Maine Sea Grant and Cooperative Extension staff members are known for having high levels of trust and access in the communities in which they work. The Cobscook Bay Resource Center is a nongovernmental organization based in Eastport, Maine, that supports community-based approaches to resource management and sustainable development. The Resource Center had previously held tidal power meetings in the community to initiate discussions about tidal power among developers and community members. They also provide support to the Cobscook Bay Fishermen's Association, which represents many of the fishermen in the area.

With these partners, we identified a nonrandom probability sample of individuals representing a diversity of stakeholder groups in the community. This included fishermen, local businesses owners, municipal leaders, teachers, and tribal representatives. From April to December 2010, we administered a semi-structured survey to a total of 38 community members from our study area (hereafter referred to as 
community interviews). In addition to identifying the relevant stakeholders, we were particularly concerned with the community perceptions and experiences related to the work of ORPC because the company is currently the furthest along in-stream MHK tidal project in the USA and because the State of Maine Governor's OETF identified it as a model for community engagement. The majority of the community interviews were not recorded, but detailed notes were taken. Those that were recorded were transcribed.

In June 2012, we held three focus groups, two with fishermen $(n=9)$ and one with community members $(n=4)$ from the areas surrounding the proposed project. Two were held in Eastport and one was held in Lubec. Focus groups lasted about an hour each and followed a discussion guide. In particular, participants were asked about their perceptions of the Cobscook Bay project and about their engagement with the developers. We chose interview and focus group participants purposively through document analysis, network sampling, and our observations. All interviews and focus groups were audio-recorded and transcribed. Focus groups also served to ground truth some of the findings from the community interviews. In addition to interviews and focus groups, we made observations throughout the research process at community meetings convened by scientists and developers and public meetings held by agency regulators as a part of the formal administrative process. These included two U.S. Coast Guard public meetings on the proposed navigation regulation for the Cobscook Bay project and two informal, public meetings where MHK scientists presented their work and sought input to the research from stakeholders. Detailed field notes were taken, and when possible, meetings were audio-recorded and transcribed.

Regulators and Developers - Methods for characterizing and documenting perceptions of non-community stakeholder groups were similar and overlapping. In order to better understand the role of regulators and developers, we conducted 12 semi-structured interviews with federal and state agency representatives and four developers. These interviews lasted between 1 and $2 \mathrm{~h}$ and followed a semi-structured interview guide. Interviews were recorded and transcribed. 
In addition to the two informal, public meetings and two U.S. Coast Guard public meetings, we also attended four informal consultation meetings between ORPC and federal and state regulatory and resource agencies, and one offshore renewable energy industry technical meeting, where stakeholders were given the opportunity to identify themselves and express their concerns. Public meetings and agency consultations were audio-recorded and transcribed. At each meeting, we took detailed field notes and collected additional available information (e.g., reports, handouts, presentations, etc.). These materials supplemented our handwritten notes.

Data Analysis - We coded all responses to the community interviews and entered data into an Excel spreadsheet for analysis. We also entered data from the interviews with agencies and developers and observations of meetings into an NVivo 9.0 database for qualitative analysis. We coded interviews for emergent patterns and themes following a modified grounded theory approach (Glaser and Strauss 1967; Strauss and Corbin 1990).

RESULTS

Stakeholder Identification

Community - When asked in the community interviews, "Who do you think would be most likely to be impacted by tidal power?," responses were residents ( $48 \%$ ), followed by fishermen ( $33 \%$ ), and then property owners, "everyone", and tourists (19\%). We view fishermen as a distinct subgroup within the broader community category because they were consistently identified in interviews and at public meetings as most likely to be impacted by tidal power. Community stakeholders interviewed were concerned that tidal power in Cobscook Bay would "restrict fishing," and many shared the sentiment that "fishermen would be the most hurt by it." In particular, scallop and urchin draggers were identified as the stakeholder group 
that would "lose some real estate" because of the perception that tidal power has the potential to restrict fishing ground.

Developers - Developers identified regulators, community (and particularly fishermen such as scallop draggers), and native tribes as stakeholders. In describing who should be on the "stakeholder list" one developer said:

I think the stakeholder list is long and arduous, and it's a fool's errand to just go to the agencies and negotiate at the agency level. I think it is important to negotiate at the local level, the community level, and all the other resource user level as it is to deal with your regulatory agencies.

Another developer specified what they perceived as community interests:

The obvious ones are the mariners, the fishermen, recreational boaters, anybody that might be impacted by the project location and equipment in the water. On the onshore station, the stakeholders include all the abutting landowners whether they are year-round or seasonal residents...and in that category I would put educational institutions in the area.

Adding to our a priori characterization, regulators and developers also identified scientists as an important stakeholder group. Developers talked about the wide range of professional expertise that was expected to come to bear on decisions regarding deployment of ocean energy devices. One ORPC representative acknowledged the important role of scientists for funding and "knowledge creation." He explained that, "...having scientists involved in your project is important for helping make all that happen."

Regulators - Agencies described themselves and other federal and state agencies as the "most active" stakeholders. A federal regulator listed agencies they viewed as relevant:

Coast Guard is very relevant, U.S. Fish and Wildlife Service, and NMFS [National Marine 
Fisheries Service]. There's various state agencies, the Maine Department of Marine

Resources [DMR] that are very relevant, State Planning Office. Of course, FERC [Federal

Energy Regulatory Commission] and the Bureau of Offshore Energy Management [BOEM].

Both federal and state agencies described their role and power as context specific and mandated by law.

In general, resource agencies were identified as having a stake when a particular resource (e.g., salmon) or issue was involved. For example, a federal regulator described the role of the different agencies in decision-making for MHK development:

Coast Guard, navigational issues. Maine DMR, fisheries issues, commercial fisheries interests. NMFS, the Marine Mammal Protection Act, Magnuson Stevens... Fish and Wildlife Service [FWS], Endangered Species Act, and marine mammals as well as diving birds...Maine Department of Environmental Protection because I do believe they have to issue a 401

Water Quality Permit for these projects...FWS and NMFS also have Section 18 of the Federal Powers Act where we can prescribe fishways... Corps of Engineers, very important, they deal with navigable waterways and they have the Rivers and Harbors Act.

Agencies also included communities on the list of stakeholders but typically after discussion of the role of the various federal and state agencies. One federal regulator identified "everybody and anybody in the Eastport and Lubec community" as stakeholders. Another said:

Obviously the communities where the tidal power facilities would be constructed would, I think very much, you would have to have them in on the discussion... fishing community, I guess.

Similarly, state regulators identified recreational and commercial fishermen (particularly scallop and urchin draggers and lobstermen), and landowners potentially impacted by siting of power lines as stakeholders. A federal regulator detailed the list of community stakeholders: 
In any particular project, there are always abutters, people who may own adjoining property may have visual or aesthetic concerns about a particular tidal project, people who may be affiliated with nongovernmental organizations who are concerned about the resources that might be impacted by a particular project, communities who may have issues regarding tax income that might come from a project or business opportunities, jobs, and then extending to contractors that might work on a particular project, there's a variety of stakeholders within each of those kinds of classes of stakeholders.

Another federal regulator summed up the list of stakeholders potentially affected by a project as, "users of the area" that are "defined on a case-by-case basis." He said:

In the case of hydrokinetics, [it is] important to get the different industries involved that are other users of the area, [the] water, where potential conflicts could occur.

Although regulators mentioned navigable waterways rights (e.g., issues of boat traffic), they acknowledged that few recreational boaters use the waters of Cobscook Bay, and there is "no commercial traffic there." Similar to developers, regulators listed Native American tribes as stakeholders. They described tribes as having "special status" and discussed how tribes were "almost always asked for their input in cases where it affects tribal resources." However, tribes were described as having "a special class of involvement and notification," and interaction with tribal representatives generally occurred at the federal level.

\section{Assessment of Stakeholder Salience}

Stakeholder groups identified in our social science research and characterized using the typology of Mitchell et al. (1997) ranged from not stakeholder to definitively a stakeholder (Table 1). Attributes of power, legitimacy, and urgency were determined based on stakeholder perspectives and our observations. 
This section provides evidence to support our characterization, although we again recognize that attributes are variable and socially constructed; thus, our analysis offers only one of several possible interpretations.

Community Stakeholders - Based on our analysis, we classify broader community members as generally dominant stakeholders because they are viewed as legitimate for the most part and they are perceived as potentially having power to impact the success of a project, but their stake is not viewed as urgent compared to fishermen (Table 1). This group includes residents, property owners, and those with recreation and navigation interests. Legal mandates require regulators and developers to consider how a project will lead to socio-economic and environmental impacts in the community, thus giving them legitimacy in the process. They are viewed as having power, as one representative of a tidal power development company indicates they can make or break a project:

Fundamentally, if you could have the world's greatest technology, the best turbine human kind has ever known but you don't have a site, number one and then number two, if you don't have a community that wants you there, it just isn't going to happen.

Here, the developer is alluding to problems that arise from NIMBY (not-in-my-backyard) groups, such as those seen in Cape Wind (Kempton et al. 2005). If community members are viewed as having an urgent claim, this group of stakeholders may also become a definitive stakeholder. One could also imagine the urgency of their claims increasing with new information on socio-economic or environmental impacts; this would shift them to being definitive stakeholders. They could also be dangerous; for example, summer tourists or part-time residents who are not viewed as legitimate because they do not live year-round or rely financially on the bay, but may have significant power (e.g., political or financial) to stop a project simply if they do not want it in the community. Some of these could be classified as NIMBY groups. Unlike many offshore wind projects (e.g., Kempton et al. 2005), we have not seen these groups emerge in the context of tidal power in Maine. 
Another group that we have not seen emerge are nongovernmental organizations (NGOs); however, they were identified in our research as a group that may have stake in the process. One regulator pointed out that NGOs that have been involved in conventional hydro such as "the Atlantic Salmon Federation might well have concerns about marine hydrokinetic." He also said, "Audubon Society who is very concerned about migratory birds...they might become involved... commercial fishing associations, they might become involved, but I have not heard of these organizations to date." When asked why these groups are not currently involved in debate surrounding MHK development, the regulator added, "I think people haven't really gotten their arms wrapped around what a hydrokinetic project is or could do, or how it might impact the resources they are interested in." It might be that as more information emerges, these groups may become more active in tidal energy development decisions and characterization would shift from discretionary to dominant or dangerous .

Fishermen - We classify fishermen as definitive stakeholders because their concerns have urgency and legitimacy. Although they hold no formal decision-making power in the process compared to the regulators' role in the permitting process, they are perceived as holding power. As one resident explained: "Loss of traditional fishing grounds will be the bone of contention. If it (tidal power) starts infringing too much (on commercial fishing) there will be a rub." Fishermen's power comes from the cultural and economic importance of fishing to the state, and there was the perception that tidal power could compete with fishermens' interests. As one fisherman we interviewed said, "Eventually they would be competing for the bottom in our bay that has historically belonged to fishermen." Additional semi-structured interviews and our observations at public meetings supported these findings. For example, one regulator said, "Loss of fishing grounds. I am sure that's an issue for commercial fishermen." Impacts on this sector will be critical to any siting decision made regarding renewable energy. Their power has already been recognized to some extent by the developer; for example, the location of the testing site was moved to accommodate 
fishermen's concerns. ORPC has taken great effort to meet with fishermen in the region throughout the process, and in making decisions going forward, one company representative described fishermen as "one of the first [stakeholder] groups that [they] would be going to."

Tribal Interests - Tribal interests in the community have both legitimacy and power in the process, and therefore, we classify them as dominant stakeholders. Federal agencies are required to notify and engage Native American tribes who have land in the project area that could potentially be affected by development. Tribes are perceived to have power due to their "special status" and because of their influence at the federal level when it comes to protecting tribal resources. In our case, federal agencies "reached out" to tribal authorities. Similarly, ORPC recognized the tribes as important stakeholders and also reached out to tribal authorities as a part of their stakeholder engagement process.

The location of the Cobscook Bay Tidal Energy Project near the reservation would seem to create immediate urgency for the local tribe, but they have not been vocal about the project. Instead, they were more involved in another proposed effort that is closer to their reservation. Another possible reason to explain why tribal interests have not been more engaged in the Cobscook Bay project may be that they do not consider the chosen location for turbine deployment to be an imminent threat. As a tribal representative explained:

It is placed in areas that lessen impacts to fishermen. It's not the best fishing grounds. It's placed to allow fishermen to keep fishing. Environmental impacts have been minimized.

Regulators - Agency representatives interviewed described themselves as key stakeholders and immediately listed all the state and federal agencies they perceived should be "at the table" to ensure that their statutory needs are met. Developers also identified agencies as a key stakeholder. We classify the public regulators and resource agencies as definitive stakeholders because this group holds legitimacy, power, and urgency in 
the process.

Agencies definitive role comes from their statutory authority in the regulatory and permitting process (i.e., legitimacy). Input from agencies during the decision-making process for hydrokinetic project licensing may determine whether or not a project will go forward, although the Federal Energy Regulatory Commission (FERC) makes the final licensing decision. These agencies essentially represent all key stakeholders in the process: the fishermen, broader community members, environmental group interests, and other members of the general public. They hold significant power in the process because they have jurisdictional authority and will make recommendations or decisions (i.e., impacts to species of concern) that can influence permitting decisions and the ultimate siting of projects, including opinions about the potential social and environmental impacts. Regulators have urgency in the process because of the timing of decisions and the limited amount of information available on MHK technology with which to base their decisions.

Despite uncertainty, regulators need to make major decisions about the deployment of new tidal energy technologies, the outcomes of which will affect coastal resources and the communities that depend on them.

Developers - In addition to the stakeholders identified in the interviews, we also include the developers as stakeholders with considerable urgency, legitimacy, and to a lesser extent power. We classify them as dependent stakeholders. They are legitimate because they will be impacted by any permitting or regulatory decision that is made regarding tidal power. We view them as having urgency, because the longer they are involved in the process, the more financial resources it costs them. Importantly, developers must continue to show progress to receive support from their investors. However, if there is wide acceptance for tidal power in the community (such as for economic development reasons), the developers hold some power in that they can decide not to pursue a project in a community if they feel the costs of environmental monitoring or mitigation are too excessive. If this is the case, they may be definitive stakeholders. At this time, we do not 
view the developers as definitive stakeholders.

Scientists - Although scientists were not identified in our a priori identification of broad stakeholder groups, developers and regulators identified them as important to the process of tidal energy development. We, including our engineering and biophysical research colleagues, can potentially direct the outcomes of the projects through the information we provide to the state, the developers, and the general public. A regulator describing his perceptions of scientists as stakeholders, said:

They've got a pretty major role in it, both the scientists developing the technology and the scientists who are out there determining what the effect of it is...a good component of the [Cobscook Bay Tidal Energy Project] is to find out what the effect is on the environment, and that's going to be conducted by scientists...in order to get the answers we need on tidal power, we need the science.

In other words, the regulator viewed scientists as stakeholders because the information they provide can impact regulatory decisions and ultimately a developer's decision regarding project feasibility.

As noted earlier, the developer also views scientists as an important stakeholder group. One representative of the developer said:

There's so much environmental work required that it's difficult to find money to do it. So it's important to have the strategic relationship with the University because the university is...a separate independent entity and is able to attract money from pools no one else can play in.

Because of the high level of uncertainty and rapidly increasing interest in tidal power, regulators and developers are turning to scientists to help them understand the potential effects of this technology in order to move the industry forward; this gives scientists some urgency in the process. We do not view ourselves as 
legitimate stakeholders, but we recognize that we ultimately do hold some power in the decision-making process-if not to the same extent as the regulatory agencies. We recognize also that our power and influence is likely impacted by funding and other institutional constraints. We, therefore, classify ourselves as dangerous stakeholders.

Perceptions About Engagement

The theme of engagement was heard from all stakeholder groups interviewed: developers, regulators, and community members, including fishermen, and this was a theme heard during all of the public meetings and focus groups observed. Here we first present how the developer describes its engagement strategy, and then turn to how stakeholders perceive this strategy.

Developer's Views of Engagement - ORPC views their engagement strategy as "transparent to stakeholders and based on lots of listening." One representative of ORPC explained that for them "it has been important to be visible and open; to leverage local talents and resources." Another described their approach this way: "We've always been pretty open. We have an open door policy in our offices. We try our best to advertise to the public, certainly respond to feedback quickly." This is all founded on their belief that "agencies give permits, communities give permission." Other lessons shared by the company representatives on stakeholder engagement include: engaging community leadership before moving through the permitting process; extending effort to identify and speak to the right people; scoping community relationships early on; and being as specific as possible to avoid antagonism from those desiring more specific information. What the developers found was that the issue was not the tidal energy turbine being in the water or the testing vessel being at anchor. Rather the issue was that the community "felt uninformed or someone didn't reach out to them." This understanding motivated the company to "make that extra effort to get some information out on the street." Indeed, an important component of ORPC's engagement strategy is to be 
present in the community. One ORPC representative said:

We want to be on the street, and it is part of why we hired people locally to be the face for the company up there...anytime you are walking down the street, or sitting in a restaurant, or standing in the checkout line at the IGA...someone can always stop you and say, 'How come you did this?' Or, 'I heard this...'

Early in the process, ORPC identified "the need to create a relationship with the fishing community." The original facilitator of the fishing industry relationship was a community nongovernmental organization, the Cobscook Bay Resource Center. An ORPC representative described that this has changed: "Now there's a subgroup [of fishermen] that meets with us directly" and suggests that because of this, they "gained support for [the] project." The developer further described the relationship between ORPC and the fishermen as one based on "advice." ORPC sought and received advice from fishermen on issues such as whom the company should talk to before they proceeded, on seasonality and other fisheries-related issues they should be aware of at different planning stages, potential hazards to navigation, and advice for how the company should communicate with the broader community about their project. The developer also described how they used input from fishermen when they put their device in the water for the first time. In describing how the company discussed siting decisions with the local fishermen, he said, "that was a very fruitful conversation because it led to the fishermen actually pointing to some places on a navigational chart, where they thought we would best fit in." Although engaging with the community and particularly fishermen was a priority for ORPC, they acknowledged that it was a challenge "to keep both conversations and relationships current and updated."

In addition to engaging with the community and fishermen, ORPC employees also described how it as important to work with the regulatory agencies. As one representative of the developer explained: "Much like how you build a relationship with the community, you have to build a relationship with the agency." 
They are doing this through transparency and communicating information, as one representative of the company explained: "We're trying to be open with our information, we're trying to be regular with our information, keep them updated with everything that going on, and just stay at the table."

Developers have also made an effort to engage with local tribal representatives. One representative of the developer said of the tribes, "We talked to them as much as you can...we do communicate with them, let them know what we're thinking, what we're doing."

Community's Perceptions of Engagement - The majority of community interviewees indicated that they liked the way ORPC has worked in the community, as indicated in the following quote: "The way it's been done so far by ORPC is a collaborative effort and that is good." In the community interviews, $79 \%$ recommended other developers take a similar approach as ORPC. Another community member commented: "ORPC has taken a lot of time listening to the community, especially fishermen." Another community member praised the company's approach as "smart" for using "local people, local resources, [and] keeping people informed in the paper."

According to the director of a local NGO, ORPC has taken a positive approach in the community because they

articulated their broad goal of developing this technology...and then asked local people for their help...developed an MOU with the local city government...kept the community informed of their plans and progress...listened to local knowledge...and then, they actually acted on what they'd learned...hired local talent....invested significantly in the local community...so far they've worked at the right scale; they haven't overpromised... undertaken an incremental scaling up of tests and growth... built relationships and established credibility...identified themselves as a partner in community development (Hopkins 2009). 
Community members (local business owners and residents) participating in our focus groups also had positive perceptions of ORPC's approach. One of these focus group participants said:

There's been a great deal of public outreach by the tidal power developers...both on an individual basis and having community meetings. They've tried to get a great deal of input from the community about...what would be appropriate, what's acceptable.

Community members felt that ORPC offered "ample opportunity" to be involved, and in terms of learning about the project, one community member said they "see stuff all the time like in the paper...[or hear] from word of mouth through one person or another that's been associated with [ORPC]." Community stakeholders also perceived company representatives as accessible and approachable: "They are downtown [in Eastport] and there's always people there, and they are very nice." A tribal representative said: ORPC has pretty much written the boilerplate for how this should be done. Having someone in the community as a go between, like [the local community member hired by ORPC], gives their project credibility in the community. [He] is upfront and has a good relationship with community members. This is very valuable.

In general, fishermen's opinions of ORPC have also been generally positive. As noted earlier, ORPC contacted local fishermen early in the process, and some of these fishermen were later hired by the company to perform various tasks. One of these fishermen, contacted directly by ORPC to discuss possible hazards to navigation posed by the proposed project, found one of the company's public presentations informative and said that "they've taken the right approach." Another fisherman also found public presentations by ORPC "very informative" and said of the company's approach, "They've made all efforts to approach fishermen and answer questions." One fisherman talked specifically about how ORPC worked with the fishermen to decide on the location of the first turbine deployment. He said, "They've worked with fishermen in finding out where to place their things and they've tried to keep them out of the way of fishermen, so far." 
Despite these positive perceptions, fishermen raised some concerns early on, such as fishermen who expressed uncertainty about the potential impacts on the fishing industry. For example, one fisherman said, in 2010, "I don't think they let us know everything," and further asked, "How much bottom they will take? How much fishing grounds will be lost? What will they do for the fishermen?"

One incidence in particular, noted by several fishermen we talked to, could have ended poorly for the company. Several fishermen spoke about ORPC's decision to pursue additional preliminary permits outside of Cobscook Bay, but in a nearby area important to local fishermen, without first seeking local input. For example, one fisherman in our focus group described their reaction to this new permit:

All of the sudden, there's a chart of the bay and this great big purple area applied for tidal power. Everybody starts saying, 'Geez, where's the hearing on that?' So it kind of soured some relationships, but they've [ORPC] mended those...There's been discussions with [ORPC] since, and people understand why they done it...They promised to be more in touch, and I believe they will be.

However, not all fishermen felt that the engagement process has been completely effective or that ORPC has responded to their needs and concerns. In particular, several Lubec fishermen offered disparate views on OPRC's engagement strategy. By water, Lubec is close to Eastport and the deployment site. It is also the site of the onshore station for cable connection to the interstate grid. By land, however, Lubec is removed (approximately $1 \mathrm{~h}$ ) from ORPC's office in Eastport. In responding to questions about their interactions with ORPC, one Lubec fisherman described their experience at the U.S Coast Guard public hearing:

We [were] told in the meeting, they said they would move the buoys [marking the location of the turbine] back from Goose Island, which they [ORPC] didn't do.

Fishermen identified Goose Island as important for urchin fishing. The perceived lack of attention to 
the fishermen's concern about a buoy located in this area, elicited the following response from a Lubec fisherman. He said, the fact that the buoy was not moved, "kinda bugs me," and further explained...that because of this "they're not credible." A problem, from these fishermen's perspective, is that the company did not engage all of the fishermen in the bay, but primarily focused their attention on those located in the town where their office was located.

Regulator's Views of Engagement - Several regulators agreed that early engagement has been essential for improving the success of ORPC's project; one regulator explained: "I think because ORPC engaged the local community so heavily that their needs were addressed." Another regulator said, "ORPC folks have generally gone about things the right way." They commented that the first contacts that they made were locals and that "it's that local outreach and local cooperation done very early that is really important." Regulators also felt the company has effectively engaged them in the process. One regulator agreed with their strategy and stated, “...at ORPC, a lot of their project managers...they've all been very good at engaging us early and often."

DISCUSSION

Numerous and diverse stakeholders affect and are affected by the process of tidal energy development. Our research contributes social science to better understand who may be affected, how they are affected, and how they have been engaged in the process of tidal energy development in Maine. We found that Mitchell et al. (1997) provide a useful framework for understanding the complex stakeholder environment relevant to tidal energy development, and we used the framework to organize our research findings and facilitate identification of the most salient stakeholders whose engagement is important for tidal power development. 
Given the Cobscook Bay project's coastal location and proximity to tribal lands, the community stakeholders (i.e., fishermen, residents, property owners, and tribes) we identified through our mixed methods research approach were not surprising (Table 1). In our study, fishermen were consistently identified by all three broad categories of stakeholders (community, developers, and regulators) as the group most likely to be impacted by tidal power development or likely to impact the process. Also not surprising was the fact that regulators and developers identified several of the same stakeholders. They both identified agencies and "abutting landowners," both relevant to the regulatory context and primary, formal role of regulators and developers. More interestingly, both regulators and developers identified scientists as stakeholders, a group we had not initially included in our a priori characterization.

Applying the Mitchell et al. (1997) typology to these findings, we characterized fishermen as definitive stakeholders (Table 1), because they hold power, legitimacy, and urgency in the process. Although residents and property owners were also viewed as important interests (and their participation in the process is mandated by statute), at present, their interests do not appear as urgent as those of fishermen, and therefore, we characterized them as discretionary. To date, there has been no organized community opposition to the Cobscook Bay Tidal Energy Project and tribal interests have been minimally involved. Lack of urgency as a key attribute to characterize these community stakeholder groups may be attributed to the salience of the issue. Tidal power development is currently more urgent to the fishermen because of the perceived physical intrusion on their fishing grounds. For other community interests, tidal power development may be out-of-sight and out-of-mind, or may not be at the top of the lists of concerns compared to other presumably more pressing concerns.

Our research and analysis using Mitchell et al. (1997) suggest that future stakeholder engagement should reflect the dynamic nature of salience. Given the nascent nature of the tidal power industry and the rapidly changing technology and permitting process (see Jansujwicz and Johnson 2013), salience is likely to change as the project unfolds, thereby requiring different levels of engagement. Some groups may become 
more or less important than others, and therefore, the appropriate engagement strategy would need to change as well. As an example, as the environmental effects of tidal turbines are better understood, environmental NGOs might ask to be included in the discussion. Similarly, attributes of power may change, and outcomes of our research suggest that stakeholder power may not necessarily be a good indicator of whether a stakeholder or stakeholder group has the potential to influence decision-making at a particular point in the process. In fact, less powerful, local actors can deploy means to delay or halt implementation of a project (Breukers and Wolsink 2007). In our case, residents and other community interests are currently not viewed as having the same level of formal power attributed to regulators responsible for licensing decisions, and NGOs (at least at this time) are perceived as having minimal power. If mobilized, however, local residents and NGOs may ultimately have more influence than would be predicted by the static use of the Mitchell et al. (1997)typology. Thus, we suggest that on-going research should track changes in typologies of salience.

ORPC's considerable efforts to engage relevant stakeholders early and often were noted by both regulators and community stakeholders, particularly local fishermen, residents, and tribal representatives. Perhaps regulators' positive perceptions of ORPC's engagement strategy should come as no surprise. After all, as Agterbosch et al. (2009, p. 404) pointed out, in the context of an uncertain regulatory landscape, most energy distributers use "a strategy of frequent and informal contact with competent authorities," and these "authority relations" support trust and facilitate coordinated action. Certainly, in the Cobscook Bay example, ORPC's proactive and frequent engagement with the agencies ensured that regulators statutory mandates were met and that all interests (developers, federal and state regulatory and resource agencies) were on the same page. However, in some instances, such a regulator-developer engagement strategy may be perceived as serving external economic interests and not the interests of the local community (Agterbosch et al. 2009). In our study, community stakeholders did not identify regulators as important stakeholders (perhaps this can be explained by a lack of clarity and understanding of the permitting and regulatory process); thus, this tension does not exist. Rather, evidence seemed to suggest that ORPC's current engagement strategy of 
public meetings, newspaper articles, and targeted meetings with specific (influential) community groups, such as the Cobscook Bay Fishermen's Association, met local needs for information.

Our results suggest that ORPC, the leading tidal power developer in the USA, has established a public engagement strategy that appears to be working well. Our empirical assessment of the Cobscook Bay process provides evidence of the claimed benefits of stakeholder participation. Most notably, we find that stakeholder engagement has shaped the decision-making process in terms of site selection for turbine deployment in Cobscook Bay and also in building (and maintaining) relationships with the community. Applying the theory of Mitchell et al. (1997) on stakeholder salience to the Cobscook Bay example, we offer insight on why ORPC's engagement process appears to be working and offer recommendations for future engagement strategies in Maine and beyond.

ORPC has engaged definitive, dominant, and discretionary stakeholders and this may explain their apparent success. By incorporating multiple viewpoints and perspectives from a number of diverse stakeholders (particularly fishermen and regulators) into their decision making process, ORPC has developed and maintained effective stakeholder relations, thereby forging an approach that appears to be resilient and adaptive to future decisions. Community response to the rapid procurement of additional preliminary permits without first seeking stakeholder input provides support for this assertion. Although the community's initial response to the new preliminary permits was one of concern, ORPC was able to explain the reasoning behind their quick decision (i.e., they wanted to claim the permits before another, out-of-state, and perhaps less trusted company jumped in), and because of trust built in the process, they were able to successfully smooth stakeholder relations before conflict escalated. At the same time, however, because the company was not as visible outside of the community in which their office was located, community concern was evident in these more distant areas. If not addressed in a timely and effective manner, community concern could lead to more organized opposition and future conflict. This is not surprising given the proposition that if people feel left out of the planning process and decision-making, they 
are more likely to oppose the process outcomes (Zoellner et al. 2008). Our findings highlight the critical importance of engaging more distant stakeholder groups and groups that perhaps, at this point, do possess the attribute of urgency, so that as information develops, future conflict can be more easily avoided.

In summary, although evidence points to the benefits of the developer's current engagement approach, it is important to note that the tidal energy industry is still in its infancy, and changes will continue to occur as new information emerges. The dynamic nature of tidal energy development highlights the importance of the process, and the importance of continued engagement, transparency, and recognition of diverse stakeholder needs and communication preferences. Our stakeholder characterization offers only a snapshot, and it will be important to continue to track stakeholder salience over time as tidal power develops. In practice, we find Mitchell et al.'s typology to be a useful tool for characterizing stakeholders at different points in the process. Outcomes of our research represent a critical first step toward informing the design of more effective stakeholder processes for renewable ocean energy development and specifically tidal power. While opportunities for stakeholder participation are specific to time, site, issue, and local values (Glicken 2000), our approach that combines empirical research with Mitchell et al.'s typology offers a practical strategy that can be used to inform stakeholder identification and engagement research in other renewable energy contexts. 


\section{ACKNOWLEDGMENTS}

This research was supported by the National Science Foundation award EPS-0904155 to Maine EPSCoR Sustainability Solutions Initiative at the University of Maine and Department of Energy award EE0000298 to the University of Maine. The authors would like to acknowledge their community partners, Christopher Bartlett, of the Maine Sea Grant and University of Maine Cooperative Extension, and the Cobscook Bay Resource Center, for their contributions to the community interviews. The authors are also especially grateful for Mr. Barlett's continued support and assistance with the community meetings, focus groups, and other outreach efforts. Finally, the authors thank all of those who were interviewed and otherwise contributed to this research. 
FIGURES

Figure 1. Map of Cobscook Bay

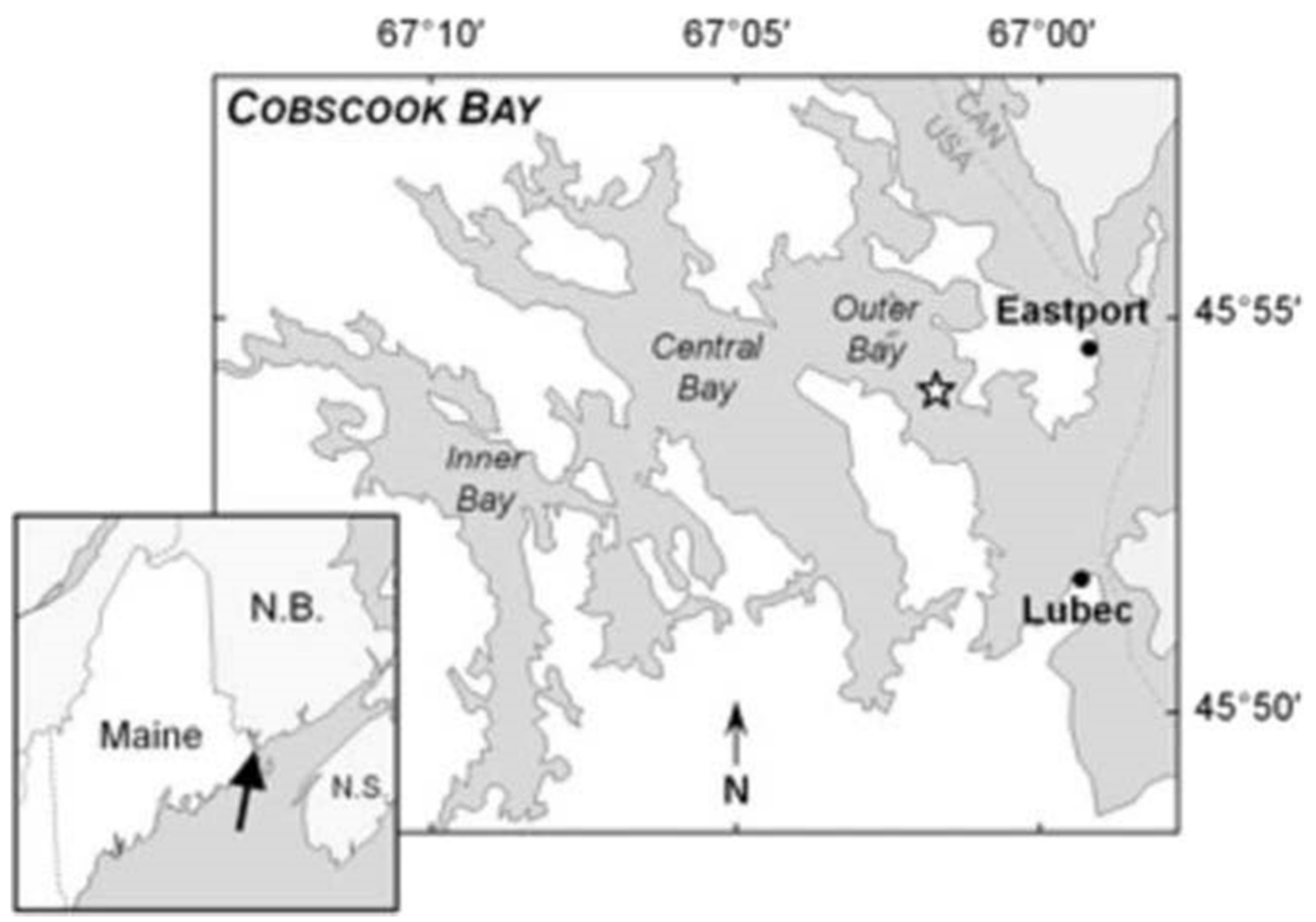


Table 1. Stakeholders identified in research and their characterization based on Mitchell et al.'s typology based on their level of power, legitimacy, and urgency

\begin{tabular}{|c|c|c|c|c|c|}
\hline Stakeholder group & Identified by: & Power & Legitimacy & Urgency & Mitchell et al.'s category \\
\hline Commercial fishermen & $\begin{array}{l}\text { - Developers } \\
\text { - Regulators } \\
\text { - Community }\end{array}$ & $\mathrm{X}$ & $\mathrm{X}$ & $\mathrm{X}$ & Definitive \\
\hline Regulators & $\begin{array}{l}\text { - Developers } \\
\text { - Regulators }\end{array}$ & $\mathrm{X}$ & $\mathrm{X}$ & $\mathrm{X}$ & Definitive \\
\hline Developers & - Regulators & - & $\mathrm{X}$ & $\mathrm{X}$ & Dependent \\
\hline Native tribes & $\begin{array}{l}\text { - Developers } \\
\text { - Regulators }\end{array}$ & $\mathrm{X}$ & $\mathrm{X}$ & - & Dominant \\
\hline Scientists & $\begin{array}{l}\text { - Developers } \\
\text { - Regulators }\end{array}$ & $\mathrm{X}$ & - & $\mathrm{X}$ & Dangerous \\
\hline Residents & - Community & $\mathrm{X}$ & $\mathrm{X}$ & - & Dominant \\
\hline Property owners & $\begin{array}{l}\text { - Developers } \\
\text { - Regulators } \\
\text { - Community }\end{array}$ & $\mathrm{X}$ & $\mathrm{X}$ & - & Dominant \\
\hline Recreational & $\begin{array}{l}\text { - Developers } \\
\text { - Regulators }\end{array}$ & - & $\mathrm{X}$ & - & Discretionary \\
\hline Tourists & - Community & - & - & - & None \\
\hline
\end{tabular}




\section{REFERENCES}

Adams, M., D. Wheeler, and G. Woolston. 2011. A participatory approach to sustainable energy strategy development in a carbon-intensive jurisdiction: the case of Nova Scotia. Energy Policy 39: 25502559.

Agterbosch, S., R.M. Meertens, and W.J.V. Vermeulen. 2009. The relative importance of social and institutional conditions in the planning of wind power projects. Renewable and Sustainable Energy Reviews 13: 393-405.

Bardach, E. 1998. Getting agencies to work together: the practice and theory of managerial craftmanship. Washington.: Brookings Institution Press.

Beard, R.E. 2009. Best practices and a case study in stakeholder and public engagement in siting ocean energy projects. University of Maine Cooperative Extension and Sea Grant.

Blackstock, K.L., G.J. Kelly, and B.L. Horsey. 2007. Developing and applying a framework to evaluate participatory research for sustain-ability. Ecological Economics 60: 726-742.

Boehlert, G.W., and A.B. Gill. 2010. Environmental and ecological effects of ocean renewable energy development: a current synthesis. Oceanography 23: 68-81.

Breukers, S., and M. Wolsink. 2007. Wind power implementation in changing institutional landscapes: an international comparison. Energy Policy 35: 2737-2750.

Bryson, J.M. 2004. What to do when stakeholders matter. Public Management Review 6(1): 21-53.

Bryson, J.M., and B.C. Crosby. 1992. Leadership for the common good: tackling public problems in a shared world. San Francisco: Jossey-Boss.

Charlier, R.H., and C.W. Finkl. 2010. Ocean energy: tide and tidal power. Berlin: Springer.

Conway, F., J. Stevenson, D. Hunter, M. Stefanovich, H. Cambell, Z. Covell, and Y. Yin. 2010. Ocean space, ocean place: the human dimension of wave energy in Oregon. Oceanography 23: 82-91.

Devine-Wright, P. 2005. Local aspects of UK renewable energy development: exploring public beliefs and policy implications. Local Environment: The International Journal of Justice and Sustainability 10: 5769.

Eden, C., and F. Ackermann. 1998. Making strategy: the journey of strategic management. London: Sage.

El Bassam, N. 2001. Renewable energy for rural communities. Renewable Energy 24: 401-408.

Elliott, D. 2000. Renewable energy and sustainable futures. Futures 32: 261-274.

Firestone, J., and W. Kempton. 2007. Public opinion about large offshore wind power: underlying factors. Energy Policy 35: 1584-1598.

Firestone, J., W. Kempton, and A. Krueger. 2009. Public acceptance of offshore wind power projects in the USA. Wind Energy 12: 183- 202. Freeman, R.E. 1984. Strategic management: a stakeholder approach. Boston: Pitman.

Gill, A.B.. 2005. Offshore renewable energy: ecological implications of generating electricity in the coastal zone. Journal of Applied Ecology 42: 605-615.

Glaser, B.G., and A.L. Strauss. 1967. The discovery of grounded theory: strategies for qualitative research.New York: Aldine.

Glicken, J. 2000. Getting stakeholder participation "right": a discussion of participatory processes and possible pitfalls. Environmental Science and Policy 3: 305-310. 
Hindmarsh, R., and C. Mathews. 2008. Deliberative speak at the turbine face: community engagement, wind farms, and renewable energy transitions in Australia. Environmental Policy and Planning 10(3): 217232.

Holmes, T. and Scoones, I. 2000. Participatory environmental policy processes: experiences from north and south. IDS Working Paper 115.

Hopkins, W. 2009. Presentation at the 2nd Annual Global Marine Renewable Energy Conference at the Carnegie Institution for Science, Washington, D.C., April 16, 2009. Available at: http://www. globalmarinerenewable.com/images/stories/2009Presentations/ WillHopkins-2009GMRE.pdf. Accessed 29 Jun 2012.

Jansujwicz, J. S., and Johnson, T. R. 2013. Understanding and informing permitting decisions for tidal energy development using an adaptive management framework. Estuaries and Coasts .doi:10.1007/ s12237-013-9678-0.

Johnson, T., and G.B. Zydlewski. 2012. Research for the sustainable development of tidal power in Maine. Maine Policy Review 21(1): 58-64.

Johnson, K., S. Kerr, and J. Side. 2012. Accommodating wave and tidal energy-control and decision in Scotland. Ocean and Coastal Management 65: 26-33.

Kempton, W., J. Firestone, J. Lilley, T. Rouleau, and P. Whitaker. 2005. The offshore wind power debate: views from Cape Cod. Coastal Management 33: 119-149.

Meltsner, A. 1972. Political feasibility and policy analysis. Public Administration Review 32: 859-867.

Mikalsen, K., and S. Jentoft. 2001. From user groups to stakeholders? The public interest in fisheries management. Marine Policy 25: 281-292.

Mitchell, R.K., B.R. Agle, and D.J. Wood. 1997. Toward a theory of stakeholder identification and salience: defining the principle of who and what really counts. The Academy of Management Review 22: 853886.

Newman, W.M., and M.G. Lamming. 1995. Interactive system design. Wokingham: Addison-Wesley. Ocean Energy Task Force (OETF). 2009. Final report of the Ocean Energy Task Force to Governor John E. Baldacci. Augusta, Maine.

www.maine.gov/spo/specialprojects/OETF/Documents/finalreport_123109.pdf. Accessed 24 May 2012

Parent, M.M., and D.L. Deephouse. 2007. A case study of stakeholder identification and priorirization by managers. Journal of Business Ethics 75: 1-23.

Polagye B., B. Van Cleve, A. Copping, and K. Kirkendall. 2011. Environmental effects of tidal energy development. U.S. Dept. Commerce, NOAA Tech. Memo. F/SPO-116. 181 pp.

Portman, M. 2009. Involving the public in the impact assessment of offshore renewable energy facilities. Marine Policy 33: 332-338.

Reddy, S., and J.P. Painuly. 2004. Diffusion of renewable energy technologies, barriers and stakeholders, perspectives. Renewable Energy 29: 1431-1447.

Reed, M.S. 2008. Stakeholder participation for environmental management. Biological Conservation 141: 2417-2431.

Reed, M.S., A. Graves, N. Dandy, H. Posthumus, K. Hubacek, J. Morris, C. Prell, C.H. Quinn, and L.C. Stringer. 2009. Who's in and why? A typology of stakeholder analysis methods for natural resource management. Journal of Environmental Management 90: 1933-1949.

Richards, C., K.L. Blackstock, C.E Carter. 2004. Practical approaches to participation. SERG Policy Brief No. 1 Macaulay Land Use Research Institute, Aberdeen.

Sharp, H. A. Finkelstein, and G. Galal. 1999. Stakeholder identification in the requirements engineering process. Proceedings of 10 th international workshop on database $\&$ expert systems applications 
(DEXA): 387-391. IEEE Computer Society Press.

Strauss, A., and J. Corbin. 1990. Basics of qualitative research: grounded theory, procedures and techniques. Newbury Park: Sage.

Van Horn, C., D. Baumer, and W. Gormley. 2001. Politics and public policy, 3rd ed. Washington: Congressional Quarterly Press.

West, J., I. Bailey, and M. Winter. 2010. Renewable energy policy and public perceptions of renewable energy: a cultural theory approach. Energy Policy 38: 5739-5748.

Zoellner, J., P. Schweizer-Reis, and C. Wemheuer. 2008. Public acceptance of renewable energies: results from case studies in Germany. Energy Policy 36(11): 4136-4141. 